\title{
TANULÓI EGÉSZSÉGMAGATARTÁSI CSOPORTOK JELLEMZŐI ÉS AZOK TERÜLETI MEGOSZLÁSA
}

\author{
KOVÁCS KAROLINA ESZTER \\ Debreceni Egyetem, BTK \\ Nevelés- és Müvelődéstudományi Intézet
}

\begin{abstract}
A tanulmány célja a középiskolás diákok tanulmányi és nem tanulmányi eredményességének vizsgálata az egészségmagatartás és tanulmányi eredményesség egyes faktorai alapján létrehozott klaszterek által. A minta 48 középiskola tanulóit tartalmazza hazánk hét régiójából és Budapestről, valamennyi évfolyam (9-12) bevonásával ( $n=2864)$. Klaszteranalízis alapján négy tanulói klaszter vált elkülöníthetővé: a deviáns (rossz egészségmagatartás és tanulmányi eredményesség), flegma (jobb egészségmagatartás, rosszabb tanulmányi eredményesség), stresszes (jobb egészségmagatartás, rosszabb mentális egészség és tanulmányi eredményesség) és kiegyensúlyozott (jobb egészségmagatartás és jó tanulmányi teljesítmény) klaszterek. Eredményeink alapján a nem, az évfolyam és a területi elhelyezkedés tekintetében a klasztertagságok megoszlásában jelentős különbségek mutathatóak ki.
\end{abstract}

Kulcsszavak: egészségmagatartás, tanulmányi eredményesség, tanulói klaszterek, területi különbségek

The aim of the study is to measure academic and non-academic achievement of high school students through creating student clusters alongside the different factors of health-behaviour and academic achievement. The sample contains 48 high schools from the seven regions of Hungary and from Budapest, involving students from each grades (from 9th to $12 \mathrm{th}$ ) $(n=2864)$. Cluster analysis was made and four student clusters were created called deviant (poor health-behaviour and academic achievement), phlegm (higher health-awareness, but lower academic performance), stressful (good healthbehaviour, but poor mental health and academic achievement) and balanced (higher health-awareness and good subjective academic performance) students. Regarding gender, grade and location, significant differences could be detected in the proportion of the cluster memberships. 
Keywords: health-behaviour, academic achievement, student clusters, territorial differences

\section{Bevezetés}

$\mathrm{A}$ z egészségmagatartás elemei közé nemcsak a protektív, azaz egészséget megőrző, valamint preventív, vagyis a megelőző viselkedéselemek tartoznak, hanem az egészséget veszélyeztető magatartási tényezők is. Ilyenek az egészségtelen táplálkozási szokások, a mozgásszegény életmód és a rizikómagatartásformák (például dohányzás, alkohol- és kábítószer-fogyasztás, korai szexuális élet). Ráadásul a különböző, egészséget befolyásoló magatartásmódok nem izoláltan léteznek, hanem egy életmód részeként, ezért ki kell emelni, hogy a különböző viselkedéses, szociális és egyéni tényezők egymással bonyolult kölcsönhatásban állnak (Németh-Költő 2014). Ennek megfelelően az egészségmagatartási csoportok létrehozásánál is együtt kell a különböző viselkedésformákat és attitűdöket figyelembe venni.

Az egészségkárosító magatartásformák közül az egyik legnagyobb veszélyforrásnak a dohányzás tekinthető. A dohányzás kipróbálásának gyakorisága az életkorral szignifikánsan növekszik. A 2014-es adatok szerint a diákok 36,2\%-a gyújtott már rá. Az 5. osztályos diákok 5,6 \%-a már kipróbálta a dohányzást, ez az arány a 7. évfolyamon $21,6 \%$, a 9. évfolyamon $45,8 \%$, míg a 11 . évfolyamon már $60,8 \%$. A növekvő tendencia valamennyi HBSC-kutatásban részt vevő országban kimutatható (Inchley et al. 2016). A dohányzási gyakoriság évfolyamok szerinti eredményei a kipróbálás gyakoriságának adataihoz hasonlóak, hiszen a gyakoriságok az életkor elörehaladtával jelentősen emelkednek. A havi prevalencia, vagyis az elmúlt 30 napban történő dohányzás aránya is növekvő tendenciát mutat az életkorral: az 5. évfolyamon 1,8\%-os, a 7. évfolyamon 8,7\%-os, a 9. évfolyamon $29,2 \%$-os, a 11 . évfolyamon pedig 39,5\%-os ez az arány. Az elmúlt évek HBSC-kutatásaival összevetve csökkenés tapasztalható (Németb-Költö 2014).

A fiatal generáció egyre több tagja körében jellemző az alkoholfogyasztás, sőt az első kipróbálás egyre fiatalabb életkorban kezdődik. A rendszeres alkoholfogyasztás kezdete 13 éves korra tehető, ám a 11 éves korosztály 1\%-a is rendszeres alkoholfogyasztó. Minden ötödik 14 éves serdülö fogyaszt hetente alkoholt (Ehrenstein 2007). A HBSC magyar eredményei alapján a dohányzáshoz hasonlóan a 7. és 9. évfolyam között tapasztalható a legnagyobb arányú növekedés a fiúk és a lányok körében egyaránt. A lányok alkoholfogyasztása az általános iskolás évfolyamokon még szignifikánsan kisebb arányú, ugyanakkor a felsőbb évfolyamokban már hasonló a fiúkéhoz, ám minden esetben magasabb a fiúk körében azoknak az aránya, akik már legalább kétszer lerészegedtek életükben. Mindazonáltal jól látható, hogy az életkor előrehaladtával nő az esély a lerészegedésre is (Németh-Költö 2014). A hazai tendenciák meghaladják a HBSC 2014 kutatás nemzetközi eredményeit, hiszen a 15 éves lányok esetében a nemzetközi átlag 9\%, míg a magyar lányok esetében $18 \%$; valamint a fiúk esetében a nemzetközi átlag 16\%, míg a magyar átlag 29\%, amely által Magyarország az ötödik helyen áll a vizsgált országok között (Inchley et al. 2016).

Ma már a „serdülő kultúra” részének tekinthető a drogfogyasztás, gyakran a serdülőkori problémaviselkedés részjelensége, amely társulhat pszichés problémákkal, de- 
presszióval, szorongással, öngyilkossági gondolatokkal, tanulási problémákkal vagy beilleszkedési nehézségekkel (Brassai-Pikó 2005; Demetrovics 2001). Az illegális szerek első kipróbálásának életkora is - akárcsak a dohányzás és alkoholfogyasztás esetében - egyre korábbra tehető. A HBSC-kutatások magyarországi adatai szerint 2014-ben a 9-11. évfolyamos tanulók 23,1\%-a fogyasztott már életében valamilyen tiltott és legális szert. A z illegális szerek kipróbálását tekintve az átlag 14,9 év (Inchley et al. 2016; NémethKöltö 2014).

Magyarországon a HBSC 2014-es adatok és a 2013-as OKM-adatok ( $N=2732)$ felhasználásával került sor a tanulói egészségklaszterek felmérésére (Kovács-NagyHegedüs benyújtva). Az eredmények alapján deviáns, flegma, kiegyensúlyozott és streszszes klaszterek létrehozására került sor, és jól látható volt az a tendencia, hogy számos tanuló tisztában van a kockázati magatartásformák káros hatásaival, azonban ez nem bír visszatartó erővel, vagyis figyelmen kívül hagyják ezen ismereteket. Jelen kutatásban célunk az volt, hogy egy komplexebb mintán kerüljön sor a tanulói csoportok felmérésére.

\section{A kutatás célja és módszertana}

A kutatás során többlépcsős rétegzett mintavétellel országos minta kialakítására került sor, összesen 48 intézmény 3015 tanulójának bevonásával, valamennyi középiskolai évfolyamról (9-12.) bevonásával. Az Országos kompetenciamérés adatbázisának felhasználásával az intézményi sajátosságok feltérképezését követően, egy adott régióból hasonló típusú középiskolák kerültek kiválasztásra annak érdekében, hogy a társadalmi háttérváltozók megfelelően kontrolláltak legyenek. A kutatásban két típusú köznevelési intézménycsoport szerepelt: a köznevelési típusú sportiskolák ${ }^{1}$, illetve a hagyományos köznevelési intézmények.

$\mathrm{A} z$ így létrehozott adatbázis a Sportiskolákban és hagyományos köznevelési intézményekben tanulók egészségmagatartása $2017^{2}$ (SHTE 2017) nevet viseli.

A kutatás célja hazánk sportiskolai és nem sportiskolai tanulóinak egészségmagatartásbeli vizsgálata, s ez alapján tanulói csoportok létrehozása a különböző egészségmagatartási szempontok mentén. Hipotézisünk szerint a korábbi kutatásunkhoz hasonló tanulói egészségmagatartási klaszterek különíthetőek el (Kovács-Nagy-Hegedüs benyújtva). Feltételezzük továbbá, hogy a klaszterek megoszlásában szignifikáns eloszlásbeli különbségek mutathatóak ki a nem, az évfolyam, valamint a területi el-

\footnotetext{
Az a köznevelésről szóló törvény hatálya alá tartozó, évfolyamos vagy korcsoportos sportági képzést biztosító köznevelési intézmény, amely a helyi pedagógiai programját - az országos sportági szakszövetség, illetve országos sportági szövetség vagy fogyatékosok országos sportszövetségének szakmai javaslata alapján, az országos sportági szakszövetség, az országos sportági szövetség vagy a fogyatékosok országos sportszövetsége és a köznevelési típusú sportiskola közötti együttmüködési megállapodásban foglaltakra is figyelemmel - sportiskolai kerettanterv alapján készíti el, és biztosítja a testnevelés tantárgy emelt szintű oktatását, valamint a helyi pedagógiai programja összeállítása során figyelemmel van a sportolók felkészítési és versenyeztetési tevékenységére, továbbá a sportági programok megvalósításával kapcsolatos felkészítéssel és versenyeztetéssel összefüggő feladatait jogi személy nonprofit gazdasági társasággal, sportegyesülettel, sportvállalkozással vagy utánpótlás-nevelés fejlesztését végző alapítvánnyal fennálló együttműködési megállapodás alapján végzi (SIOSZ 2012: 2; Kovács-Nagy 2017).

2 A projekt a Nemzeti Tehetségprogram Nemzet Fiatal Tehetségeiért Ösztöndíjának (NTP-NFTÖ-16) támogatásával valósult meg.
} 
helyezkedés (régió) alapján. Az egészségmagatartási klaszterek létrehozása során a következő faktorokat vettük figyelembe: dohányzási és alkoholfogyasztási gyakoriság, önértékelt egészségi és edzettségi állapot (5-fokú Likert-skála), szubjektív egészségtudatosság (10-fokú Likert-skála), jóllét (Well-Being Inventory, WBI-5, Susánszky et al. 2006), spirituális jóllét (Spiritual Well-Being Scale, SWBS, Cotton et al. 2005), szorongás (Child Anxiety Life Interference Scale CALIS, Lyneham et al. 2013), megküzdés (Coping Flexibility Scale, CFS, Kato 2012), egészségmagatartás (Egészségtudatos magatartás kérdőív, EMK, Nagy-Kovács 2017), valamint tanulmányi eredményesség (önértékelt, tanárok és szülők véleménye, 5-fokú Likert-skála).

\section{A kutatási eredmények bemutatása}

A változók sztenderdizálását követően került sor a tanulói klaszterek kialakítására. A klaszterek kialakításának alapját korábbi kutatásunk képezte (Kovács-Nagy-Hegedüs benyújtva). Az eredmények alapján négy klaszter vált elkülöníthetővéł ezek a deviáns, fleg$m a$, kiegyensúlyozott és stresszes elnevezéseket kapták (1. táblázat).

A klaszterek mintaeloszlása jó, s kevés hiányzó, értékelhetetlen adat (151fó) maradt a mintában. A deviáns klaszterbe azok a tanulók kerültek, akikre a dohányzás és alkoholfogyasztás nagyobb gyakoriságban jellemző, egészségi és edzettségi állapotukat rossznak ítélik meg, s tisztában is vannak azzal, hogy nem élnek egészségtudatosan; szorongásuk mértéke magasabb az átlagnál, miközben jóllétük, spirituális jóllétük és megküzdési rugalmasságuk foka is alacsony. Tanulmányi teljesítményük is rossznak mutatkozik, sőt

1. táblázat: Az egyes egészségmagatartási klaszterek és tulajdonságaik (SHTE, $N=2864$ )

\begin{tabular}{lcccc}
\hline & Flegma & Stresszes & Deviáns & Kiegyensúlyozott \\
\hline Dohányzási gyakoriság & 0,37735 & 0,36912 & $-1,92862$ & 0,31243 \\
Alkoholfogyasztási gyakoriság & 0,07489 & 0,21923 & $-0,88087$ & 0,17467 \\
Önértékelt egészségi állapot & 0,44233 & $-0,83494$ & $-0,33605$ & 0,37293 \\
Önértékelt edzettségi állapot & 0,51133 & $-0,82446$ & $-0,33412$ & 0,32122 \\
Szubjektív egészségtudatosság & 0,36293 & $-0,65548$ & $-0,61590$ & 0,43455 \\
Tanulmányi eredményesség & $-0,60108$ & $-0,29884$ & $-0,55430$ & 0,81493 \\
(önértékelt) & & & & \\
Tanulmányi eredményesség & $-0,64379$ & $-0,23253$ & $-0,68310$ & 0,85966 \\
(tanárok véleménye) & & & & 0,85530 \\
Tanulmányi eredményesség & $-0,64540$ & $-0,26489$ & $-0,65107$ & 0,57823 \\
(szülők véleménye) & 0,17791 & $-0,54284$ & $-0,84720$ & 0,570 ( \\
Egészségmagatartás & 0,11331 & $-0,42922$ & $-0,14593$ & 0,25831 \\
Megküzdési rugalmasság & $-0,17604$ & 0,49840 & 0,24905 & $-0,28383$ \\
Szorongás & 0,17769 & $-0,61391$ & $-0,42990$ & 0,45007 \\
Spirituális jóllét & & & &
\end{tabular}




\begin{tabular}{lcccc}
\hline & Flegma & Stresszes & Deviáns & Kiegyensúlyozott \\
\hline Jóllét & 0,34124 & $-0,54173$ & $-0,33435$ & 0,24274 \\
Elemszám & 693 & 677 & 431 & 1063 \\
\hline
\end{tabular}

Megjegyzés: A pozitív értékek az adott változó nagyobb súlyát, míg a negatív értékek annak fordított súlyát jelentik, vagyis minél nagyobb az érték, annál inkább jellemző az adott klaszterre az adott dimenzió, s minél alacsonyabb (negatív), annál kevésbé jellemző annak jelenléte a klaszterre. Kivételt jelent ez alól a dohányzási és alkoholfogyasztási gyakoriság, ahol a nagyobb értékek kevésbé gyakori, az alacsonyabb értékek (negatív) egyre gyakoribb előfordulást jeleznek.

tanáraikról és szüleikről is úgy gondolják, hogy rossz véleménnyel vannak róluk tanulmányaikat illetően.

A flegma klaszterbe került tanulók körében jobb egészségi paraméterek mutatkoztak: a dohányzás és alkoholfogyasztás mértéke is alacsonyabb, s nemcsak jobban vélekednek egészségi és edzettségi állapotukról ezek a diákok, de az egészségmagatartást mutató pszichológiai mutatók is pozitívak (jó egészségtudatosságot, jóllétet, spirituális jóllétet és megküzdést, valamint alacsony szorongást mutatva). Ugyanakkor ezek a diákok nem törődnek tanulmányi eredményességükkel, s így nemcsak saját teljesítményüket vélik negatívnak, hanem szüleik és tanáraik felől is negatív véleményt feltételeznek.

A stresszes klaszter olyan diákokat foglal magába, akikre bár alacsony dohányzási és alkoholfogyasztási gyakoriság jellemző, negatív megítéléssel bírnak egészségi és edzettségi állapotukat illetően, s emellett magas szorongással, és a jóllét, spirituális jóllét és megküzdési rugalmasság alacsony fokával jellemezhetőek. Mindezek mellett tanulmányi teljesítményükről is negatív véleménnyel rendelkeznek, s feltételezik, hogy szüleik és tanáraik véleménye is rossz tanulmányi teljesítményüket illetően. Ezek a diákok feltételezhetően negatív énképpel és alacsony önértékeléssel rendelkeznek.

Végül a kiegyensúlyozott klaszterbe kerültek azok a diákok, akik egyértelmüen pozitív jelzőkkel illethetőek valamennyi vizsgált változó tekintetében: ezen diákokra alacsony dohányzási és alkoholfogyasztási gyakoriság jellemző, pozitívan önértékelt egészségi és edzettségi állapottal jellemezhetőek, s emellett a jóllét, spirituális jóllét és megküzdési rugalmasság magas fokát, ám alacsony szorongási szintet mutattak. Továbbá ezen diákok jó véleménnyel vannak tanulmányi eredményességüket illetően is, s feltételezik, hogy szüleik és tanáraik is hasonló pozitív véleménnyel bírnak e tekintetben.

Ezt követően megnéztük a klaszterek megoszlását a főbb háttérváltozók mentén. Elsőként a klaszterekre jellemző nemi eloszlásokat vizsgáltuk meg, amely esetében szignifikáns eloszlásbeli különbségekről beszélhetünk $(p<0,001)$. Mindkét nem tekintetében a kiegyensúlyozott diákok vannak a legtöbben, habár a kiegyensúlyozottság a lányok körében egyértelmúen nagyobb arányban tapasztalható. Ehhez hasonlóan a deviáns klasztertagság aránya a legalacsonyabb mind a lányok, mind a fiúk körében, habár csaknem 1\%-kal nagyobb arányban jelenik meg a fiúk esetében. Jelentős különbség a flegma és stresszes klasztertagságokban olvasható, hiszen a lányok esetében a streszszes klasztertagság csaknem kétszer nagyobb valószínűséggel jelenik meg, míg a flegma klasztertagság esetén a fiúk javára beszélhetünk több mint kétszeres megjelenési rátáról (2. táblázat). 
— KOVÁCS KAROLINA ESZTER: TANULÓI EGÉSZSÉGMAGATARTÁSI CSOPORTOK JELLEMZŐI... — —

2. táblázat: Nemi megoszlások az egyes klaszterekben $(\mathrm{SHTE}, N=2864)$

\begin{tabular}{|c|c|c|c|c|}
\hline & & \multicolumn{2}{|c|}{$\mathrm{Nem}$} & \multirow{2}{*}{ Összesen } \\
\hline & & Fiú & Lány & \\
\hline \multirow{3}{*}{ Flegma } & $n$ & 435 & 222 & 657 \\
\hline & $\%$ & 33,9 & 15,0 & 23,8 \\
\hline & Adj. Res. & 7,0 & $-7,0$ & - \\
\hline \multirow{3}{*}{ Stresszes } & $n$ & 211 & 446 & 657 \\
\hline & $\%$ & 16,5 & 30,2 & 23,8 \\
\hline & Adj. Res. & $-5,1$ & 5,1 & - \\
\hline \multirow{3}{*}{ Deviáns } & $n$ & 197 & 218 & 415 \\
\hline & $\%$ & 15,4 & 14,7 & 15,0 \\
\hline & Adj. Res. & $-0,1$ & 0,1 & - \\
\hline \multirow{3}{*}{ Kiegyensúlyozott } & $n$ & 439 & 592 & 1031 \\
\hline & $\%$ & 34,2 & 40,1 & 37,4 \\
\hline & Adj. Res. & $-2,5$ & 2,5 & - \\
\hline \multirow{2}{*}{ Összesen } & $n$ & 1282 & 1478 & 2760 \\
\hline & $\%$ & 100,0 & 100,0 & 100,0 \\
\hline
\end{tabular}

Megvizsgáltuk, milyen arányban jelennek meg az egyes klaszterek a különböző évfolyamokon. Ebben az esetben is szignifikáns eloszlásbeli különbségek tapasztalhatóak

3. táblázat: Évfolyambeli megoszlások az egyes klaszterekben (SHTE, $N=2864)$

\begin{tabular}{|c|c|c|c|c|c|c|}
\hline & & \multicolumn{4}{|c|}{ Évfolyam } & \multirow{2}{*}{ Összesen } \\
\hline & & 9 & 10 & 11 & 12 & \\
\hline \multirow{3}{*}{ Flegma } & $n$ & 208 & 212 & 188 & 81 & 689 \\
\hline & $\%$ & 21,3 & 27,4 & 26,7 & 20,4 & 24,2 \\
\hline & Adj. Res. & $-2,5$ & 2,1 & 0,7 & $-0,2$ & - \\
\hline \multirow{3}{*}{ Stresszes } & $n$ & 273 & 168 & 146 & 88 & 675 \\
\hline & $\%$ & 28,0 & 21,7 & 20,7 & 22,1 & 23,7 \\
\hline & Adj. Res. & 1,2 & $-0,5$ & $-1,4$ & 0,8 & - \\
\hline \multirow{3}{*}{ Deviáns } & $n$ & 89 & 121 & 126 & 93 & 429 \\
\hline & $\%$ & 9,1 & 15,6 & 17,9 & 23,4 & 15,0 \\
\hline & Adj. Res. & $-0,8$ & $-1,3$ & 1,6 & 8 & - \\
\hline \multirow{3}{*}{ Kiegyensúlyozott } & $n$ & 406 & 273 & 244 & 136 & 1059 \\
\hline & $\%$ & 41,6 & 35,3 & 34,7 & 34,2 & 37,1 \\
\hline & Adj. Res. & 2,1 & $-0,5$ & $-0,8$ & $-1,2$ & - \\
\hline \multirow{2}{*}{ Összesen } & $n$ & 976 & 774 & 704 & 398 & 2852 \\
\hline & $\%$ & 100,0 & 100,0 & 100,0 & 100,0 & 100,0 \\
\hline
\end{tabular}


( $p<0,001)$. A kiegyensúlyozott diákok aránya valamennyi évfolyamon a legmagasabb, ám a növekvő tanulmányi terhekkel és a csökkenő egészségtudatossággal arányosan alacsonyabb arányban vannak jelen a magasabb évfolyamokon, a 12. évfolyamon például mintegy 7\%-kal kisebb arányú a megjelenésük, mint a 9. évfolyamon. Ezzel ellentétben a deviáns klasztertagság aránya az évfolyam emelkedésével folyamatosan növekszik, míg a 9. évfolyamon nem éri el a 10\%-ot a deviáns tanulók aránya, addig a 12. évfolyamon a $23 \%$-ot is meghaladja, s ezzel a második legnagyobb arányban van jelen ezen az évfolyamon. A stresszes klasztertagság aránya a 9. évfolyamon a legnagyobb, ezt követően csökken, s a 10-11-12. évfolyamon közel azonos arányokban mutatható ki. A flegma klasztertagság a 10. és 11 . évfolyamokon magasabb a gimnáziumba való beszokási nehézségekkel jellemezhető 9. és a kiemelkedő tanulmányi követelményekkel megterhelt 12. évfolyamokkal összehasonlítva (3. táblázat).

Végül a klasztertagságokban fennálló területi különbségeket vizsgáltuk meg. A szignifikáns területi különbségekhez $(p<0,001)$ tartozó értékeket a 4. táblázat és az 1. ábra szemlélteti.

A deviánsok aránya az észak-magyarországi régióban mutatkozott a legmagasabbnak (19,3\%), miközben a Dél-Dunántúlon $(9,8 \%)$ volt a legalacsonyabb a jelenlétük a tanulók körében. A flegma tanulók aránya egyértelmüen Budapesten volt a legmagasabb (37,4\%),

4. táblázat: Területi megoszlások az egyes klaszterekben (SHTE, $N=2864)$

\begin{tabular}{|c|c|c|c|c|c|c|c|c|c|}
\hline & & \multicolumn{8}{|c|}{ Régiók } \\
\hline & & Budapest & $\mathrm{KM}$ & ÉM & ÉA & DA & DD & $\mathrm{KD}$ & NYD \\
\hline \multirow{3}{*}{ 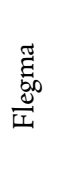 } & $n$ & 172 & 39 & 47 & 126 & 93 & 42 & 80 & 80 \\
\hline & $\%$ & 37,4 & 16,2 & 14,6 & 26,6 & 24,5 & 14,7 & 26,0 & 26,0 \\
\hline & $\begin{array}{l}\text { Adj. } \\
\text { Res. }\end{array}$ & 4,7 & $-3,1$ & $-5,0$ & 0,8 & $-1,5$ & $-1,1$ & 1,9 & 0,9 \\
\hline \multirow{3}{*}{ 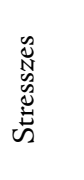 } & $n$ & 92 & 95 & 76 & 84 & 81 & 78 & 64 & 64 \\
\hline & $\%$ & 20,0 & 39,4 & 23,7 & 17,8 & 21,3 & 27,4 & 20,8 & 20,8 \\
\hline & $\begin{array}{l}\text { Adj. } \\
\text { Res. }\end{array}$ & $-3,3$ & 2,2 & 3,2 & $-1,9$ & 2,5 & $-0,2$ & $-0,9$ & 0,0 \\
\hline \multirow{3}{*}{ صี } & $n$ & 57 & 38 & 62 & 80 & 62 & 28 & 41 & 41 \\
\hline & $\%$ & 12,4 & 15,8 & 19,3 & 16,9 & 16,3 & 9,8 & 13,3 & 13,3 \\
\hline & $\begin{array}{l}\text { Adj. } \\
\text { Res. }\end{array}$ & 0,4 & $-1,9$ & 1,8 & 0,9 & 0,5 & $-3,0$ & 1,4 & $-1,7$ \\
\hline \multirow{3}{*}{ 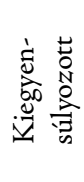 } & $n$ & 139 & 69 & 136 & 183 & 144 & 137 & 123 & 123 \\
\hline & $\%$ & 30,2 & 28,6 & 42,4 & 38,7 & 37,9 & 48,1 & 39,9 & 39,9 \\
\hline & $\begin{array}{l}\text { Adj. } \\
\text { Res. }\end{array}$ & $-2,0$ & 2,6 & 0,5 & 0,3 & $-1,2$ & 3,7 & $-2,2$ & 0,5 \\
\hline \multirow{2}{*}{ 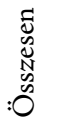 } & $n$ & 460 & 241 & 321 & 473 & 380 & 285 & 308 & 308 \\
\hline & $\%$ & 100,0 & 100,0 & 100,0 & 100,0 & 100,0 & 100,0 & 100,0 & 100,0 \\
\hline
\end{tabular}

Megjegyzés: Budapest értékeit külön kezeltük a közép-magyarországi régió értékeitől 


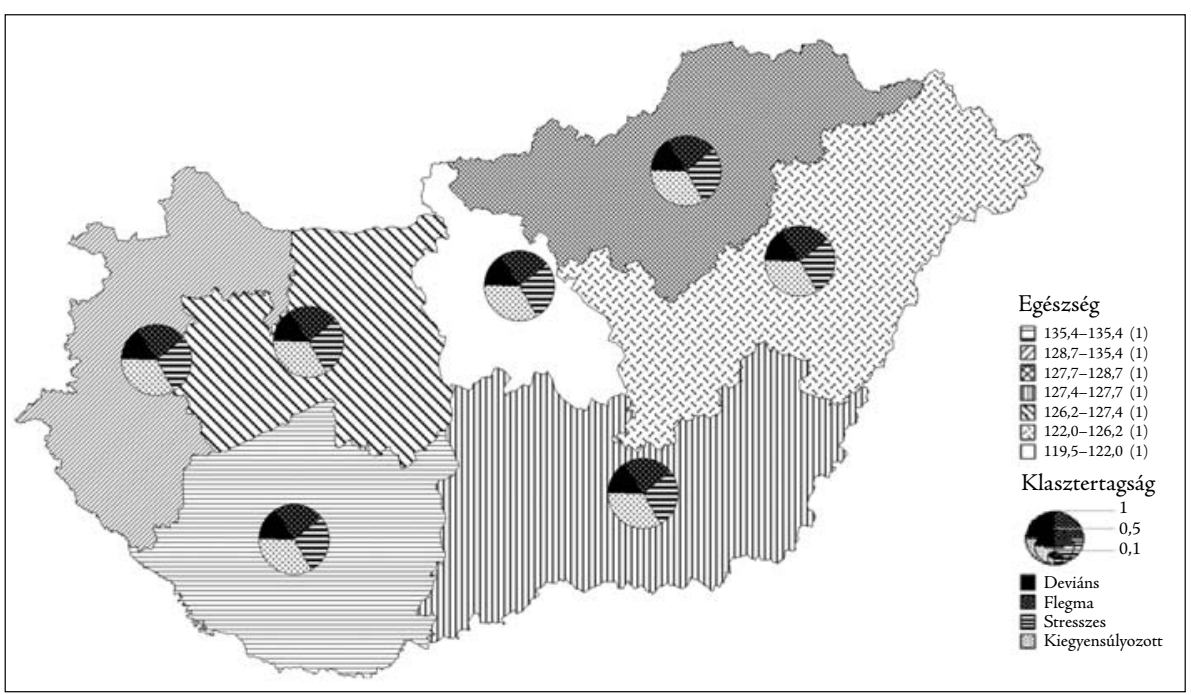

1. ábra: Az egészségmagatartás és az egészségmagatartási-eredményességi klaszterek paraméterei az ország különböző régióiban (SHTE 2017, N = 2864)

miközben az észak-magyarországi (14,6\%) és dél-dunántúli régiókban (14,7\%) volt a legalacsonyabb. A stresszes tanulók aránya Közép-Magyarországon volt kiemelkedően magas (39,4\%), míg az észak-alföldi régióban volt a legalacsonyabb (17,8\%). Végül a kiegyensúlyozott diákok aránya a dél-dunántúli régióban volt a legmagasabb (48,1\%), míg a közép-magyarországi régióban a legalacsonyabb (28,6\%). A legeredményesebb régiónak a dél-dunántúli régió mondható, mivel itt a legmagasabb a kiegyensúlyozott diákok aránya, miközben itt a legalacsonyabb a deviáns és flegma tanulók jelenléte. Az észak-magyarországi régió esetében a deviáns tanulók magas aránya mellett kompenzáló erővel bír a kiegyensúlyozott diákok viszonylag magas aránya, amely a második legnagyobb arányt jelenti. Ezzel szemben figyelemfelkeltő a közép-magyarországi régióban tapasztalható magas arány a stresszes, és a Budapesten tapasztalható magas arány a flegma diákok tekintetében, a kiegyensúlyozott és deviáns tanulók hasonló arányai mellett. A középdunántúli és dél-alföldi régiók esetében tapasztalható arányok átlagosnak mondhatók valamennyi tanulói klaszter tekintetében.

\section{Összegzés}

Mindent összevetve elmondható, hogy hipotézisünk beigazolódott, a bevont változók alapján a korábbi országos kutatásunkhoz hasonló klaszterek voltak létrehozhatók, név szerint deviáns, flegma, stresszes és kiegyensúlyozott klaszterek. A nemek tekintetében fennálló eloszlásbeli különbség szignifikáns, a lányok között nagyobb a kiegyensúlyozott és stresszes, a fiúk között pedig a flegma klasztertagság aránya. Az évfolyamok tekintetében fennálló különbség is szignifikáns, a magasabb évfolyamok felé haladva a kiegyensúlyozott és stresszes klasztertagság aránya csökkenő, a deviáns klasztertagsági arány pedig növekvő tendenciát mutat. Végül az egyes klasztertagságok megoszlásában szignifikáns területi különbségek is mutatkoztak. A legeredményesebb régiónak a dél- 
dunántúli régió mondható a kiegyensúlyozott diákok kiemelkedően magas, valamint a deviáns és flegma tanulók alacsony arányának okán. Ezzel szemben a legproblémásabb régióknak a közép-magyarországi régió, illetve Budapest minősíthető, előbbi a stresszes, utóbbi a flegma tanulók kiemelkedő aránya miatt. További kutatásaink során kitérünk az egyes klaszterek tekintetében tapasztalható különbségekre olyan további jellemzők mentén, mint a szülők iskolai végzettsége, a lakóhely településtípusa, vagy az objektív és szubjektív anyagi helyzet.

\section{IRODALOM}

Brassai, L. \& Pikó, B. (2005) Szerhasználat és családi tényezők viszonya középiskolásoknál. Addictologica Hungarica, Vol. 4. No. 1. pp. 7-29.

Cotton, S., Larkin, E., Hoopes, A., Cromer, B. A. \& Rosenthal, S. L. (2005) The Impact of Adolescent Spirituality and Religiosity on Depressive Symptoms and Health Risk Behaviour. Journal of Adolescent Health, Vol. 36. No. 6. pp. 529-536.

Demetrovics Zs. (2001) Droghasználat Magyarország táncos szórakozóbelyein. Budapest, L'Harmattan Kiadó.

Ehrenstein, C. (2007) Alkoholkonsum von Jugendlichen steigt an. http://www.welt.de/ politik/article1288489/Alkoholkonsum_von_Jugendlichen_steigt_an.html [Letöltve: 2018. 09. 26.]

Kovács K. E., Nagy B. E. \& Hegedưs R. (benyújtva) The Connection between Health Behaviour and Academic Achievement among Hungarian Adolescents in an International Comparison. Review of Applied Psychology / Revue Européenne de Psychologie Appliquée, in press.

Kovács K. E. \& Nagy B. E. (2017) Egészségtudatos magatartás alakulása a sport függvényében. Educatio, Vol. 26. No. 4. pp. 649-656.

Inchley, J., Currie, D., Young, T., Samdal, O., Torsheim, T., Augustson, L., Mathison, F., Aleman-Diaz, A., Molcho, M., Weber M. \& Barnekow, V. (2016) Growing up Unequal: Gender and Socioeconomic Differences in Young People's Health and Well-being. Health Behaviour in School-Aged Children (Hbsc) Study: International Report from the 2013/2014 Survey. Copenhagen, WHO Regional Office for Europe, 2016. (Health Policy for Children and Adolescents, No. 7.)

Kato, T. (2012) Development of the Coping Flexibility Scale: Evidence for the Coping Flexibility Hypothesis. Journal of Counseling Psychology, Vol. 59. No. 2. pp. 262-273.

Lyneham, H. J., Sburlati, E. S., Авbott, M. J., Rapee, R. M., Hudson, J. L., Tolin, D. F. \& Carlson, S. E. (2013) Psychometric Properties of the Child Anxiety Life Interference Scale (CALIS). Journal of Anxiety Disorders, Vol. 27. No. 7. pp. 711-719.

Nagy B. E. \& Kovács K. E. (2017) Egészség-magatartással kapcsolatos attitűdök vizsgálata középiskolás és egyetemista fiatalok körében. Orvosi Hetilap, Vol. 158. No. 44. pp. 1754-1760.

Németr Á. \& KöLtő A. (eds, 2014) Egészség és egészségmagatartás iskoláskorban 2014. Az Iskoláskorú gyermekek egészségmagatartása elnevezésü, az Egészségügyi Világszervezettel együttmüködésben megvalósuló nemzetközi kutatás 2014. évi felméréséröl készült nemzeti jelentés. Budapest, Nemzeti Egészségfejlesztési Intézet.

SIOSZ (2012) Sportiskolák Országos Szövetségének Módosításokkal Egységes Szerkezetbe Foglalt Alapszabálya. http://www.siosz.hu/dokumentum/sioszalapszabalyzat-terv.pdf [Letöltve: 2018. 09. 26.] 
Susánszky É., Konkoly T. B., Stauder A. \& Kopp M. (2006) A WHO jól-lét kérdőív rövidített (WBI-5) magyar változatának validálása a Hungarostudy 2002 országos lakossági egészségfelmérés alapján. Mentálhigiéné és Pszichoszomatika, Vol. 7. No. 3. pp. 247-255.

A cikk a Creative Commons Attribution 4.0 International License (https://creativecommons.org/licenses/ by/4.0/) feltételei szerint publikált Open Access közlemény, melynek szellemében a cikk bármilyen médiumban szabadon felhasználható, megosztható és újraközölhető, feltéve, hogy az eredeti szerző és a közlés helye, illetve a CC License linkje és az esetlegesen végrehajtott módosítások feltüntetésre kerülnek. (SID_1) 